\title{
Samuel Beckett and the Fantasy of Lithic Preservation
}

\begin{abstract}
:
Across his novels and shorter texts, Beckett engages frequently with forms of preservation fantasy: the belief that engraved language can extend an individual's life beyond the biological limits of the body. I argue that Beckett uses the inscription of proper names to reimagine textual immortality as an inherently material desire. Vital to this inquiry is Michel Serres's allotropic distinction between the hard and the soft [le dur et le doux], anticipated in Molloy. While the epitaphic tradition relies upon hard materials such as stone and metal to preserve lettering, Beckett's interest in excrement ("First Love") and mud (How It Is) remaps inscription onto immanence. Rather than seeking immortality through lithic preservation, Beckett's characters yearn to "return to the mineral state," to have their bodies subsumed and dispersed throughout a greater container. Explicating Beckett's material imagination reveals seldom considered source material including Frank Wedekind's Lulu Cycle and biologist Ernst Haeckel's theory of Urschleim.
\end{abstract}

Author: Hunter Dukes is a PhD candidate in English at the University of Cambridge, Peterhouse. His dissertation examines the fantastic beliefs surrounding inscriptions of proper names in twentieth-century literature and visual art, with an emphasis on texts by James Joyce, Samuel Beckett, and Don DeLillo. He keeps a log of his projects at www.hunterdukes.com.

Keywords: Samuel Beckett / inscription / proper names / materiality / nonhuman 


\title{
Samuel Beckett and the Fantasy of Lithic Preservation
}

\author{
Yes; even stone has got something to fight for. It's dead, and will do everything it \\ can to save itself from being chiselled into life. ${ }^{1}$ \\ —When We Dead Awaken, Henrik Ibsen \\ Do we have to be human forever? Consciousness is exhausted. Back now to \\ inorganic matter. That is what we want. We want to be stones in a field. ${ }^{2}$
}

—Point Omega, Don DeLillo

\section{the Endurance of Epitaphs}

In Samuel Beckett's "First Love" (1946), an unnamed speaker wanders through a graveyard, "culling the inscriptions" he finds written on stone. ${ }^{3}$ Walking amongst the headstones, he contemplates his own memorialisation through a self-authored epitaph. "Hereunder lies the above who up below / So hourly died that he lived on till now". "The alternation between the above and below creates a dizzying comic effect, displacing the body of the speaker by attempting to situate it. "Above" stands for both the proper name that would hypothetically precede the epitaph, as well as the living speaker's aboveground body. "Below" spatially situates the corpse under the inscription, as if it too were written in stone. The epitaph implies that after death the speaker will be split between two centres: the name inscribed "above" and his decaying remains buried "below".

Beckett's epitaphic uncertainty bears a striking resemblance to another text that opens with a son visiting his father's grave. In Charles Dickens's Great Expectations, Pip also culls inscriptions, finding the references to "above" and "below" similarly confusing. "My construction even of their simple meaning was not very correct, for I read "wife of the Above' as a complimentary reference to my father's exaltation to a better world; and if any one of my deceased relations had been referred to as 'Below', I have no doubt I should have formed the worst opinions of that member of my family". In Pip's graveyard, "above" and "below" map both the spatial relationship between semiotic inscription and interred remains, as well as the larger theological ordering of heaven and hell. The influence of Dickens on the early work of Beckett has been largely ignored by multiple generations of scholars. This is due in large part to the persistence of a narrative that Beckett came of age almost exclusively on a diet of non-Anglophone authors and thinkers. ${ }^{6}$

The lack of critical attention to Great Expectations is surprising, given Beckett's citation of the work in his essay "Dante ... Bruno . Vico .. Joyce" (1929). Discussing the way in which 
Joyce recognizes "the importance of treating words as something more than mere polite symbols", he places this tendency in lineage with Shakespeare's use of "fat greasy words to express corruption" and Dickens's "description of the Thames in Great Expectations". 7 With a well-known rhetorical climax, Beckett compares Joyce's language to a system of signs in which form and content are one. "Here is the savage economy of hieroglyphics. Here words are not the polite contortions of 20th century printer's ink. They are alive. They elbow their way on to the page, and glow and blaze and fade and disappear". ${ }^{8}$ What Beckett is describing is the fantasy of the ideogram: a desire to enhance the phonetic alphabet with certain mimetic properties. The savage economy of hieroglyphics is the efficient one-to-one correspondence between representational symbols and the things they represent through visual iconicity or sound symbolism. As opposed to the phonetic alphabet, writes David Abram, "[t]he pictographic glyph or character still referred, implicitly, to the animate phenomenon of which it was the static image". ${ }^{9}$ By calling Joyce's phonetic language "alive", Beckett is commenting upon the various registers (visual, sonic, semantic) on which a text like Finnegans Wake encodes meaning.

When the opening pages of Great Expectations are read alongside this theory of language, it becomes clear that Beckett's allusion to Dickens is not incidental.

As I never saw my father or my mother, and never saw any likeness of either of them (for their days were long before the days of photographs), my first fancies regarding what they were like, were unreasonably derived from their tombstones. The shape of the letters on my father's, gave me an odd idea that he was a square, stout, dark man, with curly black hair. From the character and turn of the inscription, "Also Georgiana Wife of the Above," I drew a childish conclusion that my mother was freckled and sickly. ${ }^{10}$

Here the paratextual properties of graphology gain an imaginative representational capacity. The script of inscription contains more information than the words inscribed. By comparing the letters to proto-photographs, Pip foregrounds the yearnings that undergird the epitaphic tradition. This "unreasonable" belief presupposes that the endurance of a person's name, characteristics, or accomplishments grants some form of immortality. Pip pushes epitaphic preservation to its imaginative limits by fantasizing that lithic typography is "alive" like Joyce's language: able to capture the proper names of the dead as well as aspects of appearance and character. He goes as far as to imply that his deceased brothers-who are memorialized beside the grave as five stone lozenges - have, in some cryptic way, become stone itself.

Across his novels and shorter texts, Beckett engages frequently with this kind of preservation fantasy: the belief that engraved language can extend an individual's life beyond the biological limits of the body. My contention is that Beckett uses the inscription of proper names to reimagine textual immortality as an inherently material desire. Vital to this inquiry is Molloy's anticipation of Michel Serres's allotropic distinction between the hard and the soft [le dur et le doux]. While the epitaphic tradition relies upon hard materials such as stone 
and metal to preserve lettering, Beckett's interest in excrement ("First Love") and mud (How It Is) remaps inscription onto immanence. Rather than seeking immortality through lithic preservation, Beckett's characters yearn "to return to the mineral state," to have their bodies subsumed and dispersed throughout a greater container. ${ }^{11}$ Explicating Beckett's material imagination reveals seldom considered source material including Frank Wedekind's Lulu Cycle and biologist Ernst Haeckel's theory of Urschleim. Questions about the materiality of writing ultimately become questions about crossings between the human and nonhuman, as bodies blend and blur with cromlechs (Watt), and cremation ashes disperse across pub floors (Murphy).

By drawing together onomastics, epitaphic endurance, and stone to make an argument about Beckett and the nonhuman, I show that topics which have been treated as distinct questions in the study of Beckett's prose are, in fact, intimately entwined. Benjamin Keatinge (2007) is the only scholar to have previously considered Beckett's mineral fantasies, arguing that the author exhibits an "unusual emotional investment in inorganic matter". ${ }^{12}$ In recent years, numerous critics have tried to make sense of Beckett's naming protocols ${ }^{13}$, fascination with lyric and epitaphic traditions ${ }^{14}$, and the relationship between writing and life ${ }^{15}$. If, as the aphorism goes, there are "no theoretical graveyards" in Beckett Studies, new research should seek to unify and integrate a field increasingly fragmented by seemingly disparate research agendas. ${ }^{16}$ By doing so, this article implicitly stages Beckett's corpus as particularly receptive to the nonhuman and material turns in literary studies. ${ }^{17}$

\section{Beckett's Preservation Farce}

Thinking about the epitaphic tradition through Dickens connects Beckett to a lineage of poets and writers concerned with language and the materiality of immortality. Aaron Kunin has called this particular mode the poetics of "preservation fantasy" ${ }^{18}$ Kunin builds upon Allen Grossman's suggestion that "the kind of success which poetry facilitates is called "immortality", and that poetry facilitates immortality through "the conservation of names". ${ }^{19}$ Here the conservation of names refers to a protocol similar to Pip's stone photograph: a belief that the proper name preserves a certain type of presence when inscribed in stone. This form of endurance is distinct from the desire to live forever, for it does not guarantee continued subjectivity, only memorialization in the cultural sphere. "Death is a point of aperture, not closure; not a guarantee of wholeness, defining the person as a complete unit, but a mark of division within the person". ${ }^{20}$ As in the epitaph of "First Love", death marks a rupture between the material body and the engraved name. "The stone, always older than the words inscribed in it, is the principle of continuity of the words inscribed which are its occasion as an object of attention". ${ }^{21}$ At the moment the body fails, inscription steps in as a material surrogate.

Stretching from Shakespeare through Yeats, lithic preservation fantasies are a staple of the Anglophone lyric tradition. ${ }^{22}$ In "First Love", Beckett knowingly satirizes this tradition by inscribing the inamorata's name in a heifer pat. From the moment she is introduced, the name "Lulu" is of more interest to the speaker than Lulu herself. While the culler remembers her 
first name, he has forgotten her family name. "I should have made a note of it, on a piece of paper", he reflects. "I hate to forget a proper name". ${ }^{23}$ With the name he does remember, Beckett's narrator finds himself "inscribing the letters of Lulu in an old heifer pat". ${ }^{24}$

Would I have been tracing her name in old cowshit if my love had been pure and disinterested? And with my devil's finger into the bargain, which I then sucked. Come now! My thoughts were all of Lulu, if that doesn't give you some idea nothing will. Anyhow I'm sick and tired of this name Lulu, I'll give her another, more like her, Anna for example, it's not more like her but no matter. $^{25}$

In direct opposition to enduring mediums like stone and metal, Beckett chooses excrement for the site of inscription - a waste product, the final form of decomposition before organic matter is returned to an undifferentiated state in the earth. Moments earlier, the speaker uses the phrase "history's ancient faeces", describing patriotic events as sites where "nauseated time has dropped a nice fat turd". ${ }^{26}$ To inscribe Lulu's name in excrement is to condemn her memory to the waste matter of history. It is also to play on the scatological punning of "looloo". Here we hear echoes of Joyce's Finnegans Wake, still fresh in Beckett's mind after his partial translation of Work in Progress. Comparing history to faeces recalls Shem the Penman, who writes "cyclewheeling history" across his skin using ink homemade from excrement. ${ }^{27}$ Tellingly, moments after recounting the inscription, the narrator renames Lulu to Anna-obscuring any sort of endurance normally provided by the preservation of names.

The name "Lulu" has particularly resonant associations, given Beckett's interest in cinema and German Expressionism. This passage has been subjected to various interpretations since its French publication (1970) and authorized English translation (1973). Julia Kristeva read Lulu as a corruption of "lolly", signifying a lack of differentiation from the mother's breast ${ }^{28}$, while Chris Ackerley has argued that Lulu draws ironic parallels to Flaubert's Un coeur simple, which features a stuffed parrot named LouLou. ${ }^{29}$ The true source of Beckett's "Lulu" lies buried in an endnote from James Acheson's essay "Beckett and the Heresy of Love", which mentions in passing Peter Falkenberg's suggestion that the name could be lifted from the plays of Frank Wedekind. ${ }^{30}$ Beckett does more than allude to Wedekind, however. The trope of changing Lulu's name to Anna is directly borrowed from Erdgeist (1895), where Lulu is renamed as Eve.

SCHWARZ. I love you, Nelli.

LULU. My name isn't Nelli. (SCHWARZ kisses her)

It's Lulu.

SCHWARZ. I shall call you Eve. ${ }^{31}$

This nominal ambivalence is anticipated a few lines earlier, when the character Dr. Schön asks: "Do you think a name can make so much difference?" 32 While Beckett's Lulu is a prostitute, Wedekind's Lulu, with her economically motivated marriages and irresistible 
seductions, cuts a not dissimilar figure. Beckett was certainly aware of Wedekind's work while writing "First Love". During his travels through Hamburg in October 1936, Beckett purchased a copy of Karl Heinemann's Die Deutsche Dichtung; Grundriss der deutschen Literaturgeschichte. ${ }^{33}$ Having nothing else to read on Christmas Day, he proceeded to digest Heinemann's section on Wedekind. Beckett would have also known Wedekind's work from his close reading of J.G. Robertson's A History of German Literature (1902), which devotes a section to the playwright's "grotesque" realism. ${ }^{34}$

In addition to the intentionality behind Beckett's substitution of "Anna" for "Eve", the exchange of one palindromic name for another offers insight into the connection between preservation and the proper name. There is a hint of the Adamic in this passage, for Lulu is renamed in both Beckett and Wedekind, just as Eve is named by Adam in Genesis 3:20. Noah Jonathan Jacobs, in his poetic retelling of the garden scene, elaborates on the connection between palindromes, Adamic appellation, and writing names with fingers.

Adam now turned to Eve and with graceful levity introduced himself with the sentence, "Madam, I'm Adam"- the earliest instance, if we can rely on an old account, of a palindrome, that is, a phrase that reads the same whether read backward or forward. This intricate figure is known as "versus diabolici", for the Devil is said to have concocted it and then to have whispered it to Adam. Its diabolical character lies in its circular form which denies the irreversibility of time. This seems to defy common sense. [...] The moving finger writes, and, having writ, moves on. ${ }^{35}$

To deny the irreversibility of time is to further play upon the connection between lithic inscription and the proper name. The engraved name is supposed to carry a person's memory forward into future moments. The reader's act of traversing a proper name enacts this process on a smaller scale of time - as the name endures from one moment to the next. If the name can be read both forward and backward, then a circular phonetics implies a circular temporality. Beckett had a particular ear for palindromic names like "Eve" and "Anna" after his work with Joyce. The choice of "Anna" echoes Anna Livia Plurabelle, while the lapsarian connection surfaces in the Aeolus chapter of Ulysses through the voice of Lenehan: "Madam, I'm Adam. And Able was I ere I saw Elba".36

Beckett seems aware of the biblical implications of palindromes, or, "versus diabolici", for he has his narrator write Lulu's name with his "devil's finger". The devil's finger or middle finger- "digitus tertius, digitus diabolic", as he glosses in his Dream Notebook ${ }^{37}$-places "First Love" in constellation with Beckett's mention of the finger of Christ in his poem "Serena III" (1933). "Jesus Christ Son of God Saviour His Finger / Girls taken strippin that's the idea". 38 As David Wheatley has argued, these "girls taken strippin" are possibly prostitutes (like Lulu), for Beckett alludes to Dublin Bay's Bull Island earlier in the poem, the proposed location for Buck Mulligan's "sex farm" in Ulysses. ${ }^{39}$ The juxtaposition of Jesus Christ's finger and these "women of the night" strongly alludes to John 8:6, the passage in which Jesus uses his finger to write on the ground while the Pharisees present a woman 
taken in adultery. While it remains an exegetical mystery as to what word was traced, the finger becomes the site of intersection between the woman's adulterous love and the loving forgiveness of Christ. And yet, the next biblical line- "He that is without sin among you, let him first cast a stone at her"-ripples back up the chain of associations to Beckett's "First Love", implying that proper names, inscription, and stone have other intersections beyond epitaphic endurance. ${ }^{40}$

\section{Watt's Reverse Metamorphosis}

In Watt, Beckett takes the tradition of preservation fantasy literally, imagining a character turned to stone and engraved with initials. One day, Arsene decides to leave Mr. Knott's house after a certain psychological event. While his life was happy up to a point, suddenly something slipped. "There is a great alp of sand, [...] when no one is looking, no one listening, in tiny packets of two or three millions the grains slip, all together". ${ }^{41}$ In this granular depiction of consciousness, geological events and psychic incidents take the form of particulate systems. Arsene offers a decentralized vision of the self, in which a coherent subject is spread out across several million particles, separate yet connected. A few pages later, he fantasizes that these particles cohere, rendering his body into a large, lithic mass.

$[\mathrm{P}]$ erhaps longing to be turned into a stone pillar or a cromlech in the middle of a field or on the mountain side for succeeding generations to admire, and for cows and horses and sheep and goats to come and scratch themselves against and for men and dogs to make their water against and for learned men to speculate regarding and for disappointed men to inscribe with party slogans and indelicate graffiti and for lovers to scratch their names on, in a heart, with the date, and for now and then a lonely man like myself to sit down with his back against and fall asleep, in the sun, if the sun happened to be shining. ${ }^{42}$

The metamorphosis from man into stone is anticipated earlier in the monologue when Arsene describes his condition as "the reversed metamorphosis. The Laurel into Daphne". ${ }^{43}$ Like the laurel turning back into the goddess Daphne, Arsene's transformation reverses standard mythological state changes between the human and nonhuman. While Pygmalion is carved from a block of stone to become a living, breathing woman, Arsene fantasizes he will become a petrified feature of a nonhuman landscape. One is reminded of Beckett's account of Jack Yeats's wit, in which landscape and body merge. "I said to Jack Yeats: 'This inhuman landscape evokes - provokes - the inhuman in oneself.' He said: 'Invokes, I think"". Arsene's transformation is not so much evocation as invocation, emerging as an imaginative canvas for different kinds of inscription. Once again we find a similar configuration of excrement, proper names, and stone. His body is figured as both a petric pissoir as well as the site of inscription for lover's names. Stone is entwined with preservation and contrasted to digestive disintegration, as "party slogans" and lovers' names (dated like epitaphs) are granted continued endurance upon Arsene's rocky face. 
Arsene's use of "cromlech" grounds his metamorphosis within certain mythological traditions of the British Isles. A Welsh word with Irish and Gaelic equivalence, "cromlech" designates a type of curved stone structure commonly found in Wales, Devonshire, Cornwall, and Ireland. In many $18^{\text {th }}$ and $19^{\text {th }}$ century accounts of these monuments, the stone is often associated with druidic metamorphosis. In Irish Druids and Old Irish Religions (1864), James Bonwick discusses how dolmens and cromlechs were once thought to mark the burialplace of a giant or hero. ${ }^{45}$ While these stones might have functioned as mythological gravestones, they were also entwined with the living - for there was a belief that druids were able to turn living humans into stone. In one account, which he sources from the Book of Leinster, Bonwick describes a druid named Mog Ruth who "transformed three noisy northern Druids into stones". ${ }^{46}$ John Toland also relays transformations between humans and stones in his History of the Celtic Religion and Learning (1726), where he writes that "the common people [of Ireland] believe these Obeliscs to be men, transform'd into stones by the magic of the Druids". ${ }^{47}$ And yet, once turned to stone these transformed subjects were not always silent. Writing about Logan stones - balanced rocks capable of seesaw movement-Hargrave Jennings (1879) found language in cromlechs and other lithic monuments. "We think that there is very considerable ground for concluding that all these mounted stones were oracular, or, so to express it, speaking". ${ }^{48}$ It would be incorrect to think of this as a mythological phenomenon uniquely Irish. In the $12^{\text {th }}-13^{\text {th }}$ century Welsh Mabinogion story of "Peredur the son of Evrawc", the hero meets with "a black warrior who arises from a cromlech, or standing stone", revealed to be "the dead hero who lies buried beneath it". ${ }^{49}$ While it is difficult to know if these myths bled into Beckett's choice of "cromlech", the mysterious island full of druid remains in Malone Dies suggests some knowledge of druidic lore, whether formal or colloquial.

There is an etymological pun implicit in Arsene's transformation into a cromlech, of which the classically trained Beckett would have been aware. One of the most humorous sections in Watt concerns Ernest Louit and the defence of his dissertation entitled "The Mathematical Intuitions of the Visicelts". Beyond its association with the Celts and their languages, there is a secondary meaning of "celt", which evokes Arsene's lithic inscription and Beckett's preservation fantasy. Brian O’Nolan, writing as Myles na gCopaleen in The Irish Times a few years after Beckett finished the manuscript of Watt, explicates this other meaning.

Just what is a celt? Fowler says that a celt is "Bronze or stone (or iron) chiseledged pre-historic implement. (wd. founded on a perh. false reading in Vulgate of Job xix. 24-style ferreo et plumbi lamina, vel celte (v.l. certe) sculpantur (- "O: .t (my words) were graven with an iron pen and laid in the rock forever!" $) .50$

According to this etymology, verified by the most recent Oxford English Dictionary, the word "celte" may have been a misreading of the Latin "certe", meaning surely. The scholastic side of Beckett would have no doubt enjoyed the layered irony implicit in the word for a stylus-like tool arising from misreading a passage about inscription. It also speaks a larger truth about the preservation of text. Even if words are "graven with an iron pen and 
laid in the rock forever", it does not guarantee they will be transmitted intact. When the other meaning of "celt" is taken into account, there is a perverse etymological implication that Arsene's fantasy of inscriptive transformation is entwined with a desire to somehow become Celtic.

Encoding humour at this etymological level would not have been beyond Beckett. Watt is a novel continually aware of the "Celtic Twilight" fostered by writers like W.B. Yeats, Lady Gregory, and George Russell ( $A E$ ), and filled with jokes at the expense of Celtic identity. The novel ends with Mr. Case, a railway signalman, reading Songs by the Way by George Russell-a collection whose front matter to the third edition features a critic from The Scotsman praising Russell's "intangible iridescence [...] which makes the chief charm in the poetry of the recent Celtic revival". ${ }^{51}$ As Emilie Morin argues, by putting the volume in the hands of "the aspirational lower middle classes", Beckett interrogates "the models of community engagement pioneered by Russell and Yeats", displaying "concern for the powerful circles of influence which they spawned". ${ }^{52} \mathrm{Mr}$. Case is reminiscent of E.M. Forster's Leonard Bast in Howards End-a character whose desire for self-improvement eventually results in the annihilation of his very self. This is not the only tongue-in-cheek treatment of an Irish-Celtic identity that sets itself at odds with English cultural heritage. Discussing an idiomatic Irish bull, Arsene finds himself preoccupied with distinction between English and Irish expressions: "what I think the English call six of one and half a dozen of the other [...] Or do I confuse them with the Irish?" 53 Here the logic of a "bull"-a distinction that collapses into indistinction - is used to provocatively contrast and then conflate perceived differences in English and Irish expression. Later, the narrator Sam describes Watt's unparsable language - nonsense produced through a system of mathematical inversions - as "so much Irish to me", parodying Casca's incomprehension of Cicero's Greek in Shakespeare's Julius Caesar. ${ }^{54}$

Much of Beckett's engagement with Ireland comes refracted through a French prism. Arsene's transformation is in many ways a refashioning of Marcel Proust's description of the transmigration of Celtic souls in Swann's Way.

I feel that there is much to be said for the Celtic belief that the souls of those whom we have lost are held captive in some inferior being, in an animal, in a plant, in some inanimate object, and so effectively lost to us until the day (which to many never comes) when we happen to pass by the tree or to obtain possession of the object which forms their prison. Then they start and tremble, they call us by our name, and as soon as we have recognised their voice the spell is broken. We have delivered them: they have overcome death and return to share our life. ${ }^{55}$

Proust offers a prototype for the lithic Arsene, as the Celtic soul, transferred into an inanimate object, becomes capable of engaging with passersby through nominal invocation. There are further Joycean parallels here as well. Bloom uses the word "metempsychosis" for the first time in the Calypso episode of Ulysses, explaining to Molly that "It's Greek: from 
the Greek. That means the transmigration of souls". In a typically earthy response, she dismisses Bloom's airy talk: "O, rocks! she said. Tell us in plain words". ${ }^{6}$ Arsene's transformation plays between Molly and Bloom, offering a vision of transmigration grounded in a rocky body.

\section{The Hard and the Soft}

'Brain hardening \& softening simultaneously makes Joyceology impossible'57 -Beckett to Georges Duthuit, 27 July, 1948

While names, stone, and engraving appear in a recurring constellation across Beckett's work, we have not yet uncovered the conceptual link. What is it about a person's name that serves as a hinge between worlds material and immaterial, between the rough surface of rocks and the almost gaseous elusiveness of consciousness? Inscription highlights the peculiar properties of proper names. They exist within the visible world - they can be traced and culled when written in stone-but they also designate and refer to the self, that seat of subjectivity that includes the body but exceeds its contours. Just as Beckett describes the advent of a "no-man's land" between the subject and "the world of objects" in his essay "Recent Irish Poetry," the proper name connects the organic body to the inorganic landscape when inscribed in stone. ${ }^{58}$ Put in different but equivalent terms, proper names mediate between what philosopher Michel Serres has called the hard and the soft, a distinction Beckett anticipates in Molloy.

The novel's preoccupation with the transition between material states finds a distillation in its protagonist's name, for "Molloy" shares roots with words that indicate a certain level of malleability. The detective Moran is the one to point this feature out, when trying to decide whether to use the name "Molloy" or "Mollose", writing that "the second seemed to me perhaps the more correct. But barely" ${ }^{59}$ Why does Mollose seem more correct than Molloy? To answer this we have to play a game of speculative etymology, alike in kind to the method Socrates derives in Plato's Cratylus. - Ose as a suffix is used to form adjectives from nouns, imbuing them with the sense of being "full of" or "abounding in" a certain quality. Historically, "Oy" has been an Irish-English word for grandchild or descendent. "Mo "Moll" is a syllable related to a family of words like "molliate", "mollient", and "mollified"-all which share a sense of softness and malleability. Molloy himself is aware of this sense of softness built into his name: "she had poisoned my beer with something intended to mollify me, to mollify Molloy, with the result that I was nothing more than a lump of melting wax, so to speak". 61 Thus, "Mollose" means something like "full of or abounding in soft formlessness" while "Molloy" means "the descendent from something soft and malleable". Since the "moll" quality of Molloy is a character judgment and not a claim about his ancestry, Moran is right. "Mollose" is indeed more "correct" than "Molloy".

While Molloy's description of melting wax recalls Descartes famous thought experiment in Meditations of First Philosophy, it also reveals relationship between endurance and allotropy in Beckett's text. Later in the Trilogy while discussing the materiality of writing, Malone 
cannot decide which form of inscription better endures: the hard or the soft. "But I say to myself, Between a hard lead with which one dare not write too lightly, if a trace is to be left, and a soft fat lead which blackens the page almost without touching it, what possible difference can there be, from the point of view of durability." 62 Malone's puzzlement mirrors a scene where Molloy is served tea and bread in the custody of a police officer: "this little pile of tottering disparates, in which the hard, the liquid and the soft were joined, without understanding how the transfer had been effected". ${ }^{63}$ Molloy's body is the midpoint between the hard and the soft, just as "Molloy" etymologically designates a person capable of shifting between these various states.

While Molloy establishes continuum between the hard, the liquid, and the soft, Serres finds continuity between "hard" science and the soft flow of information. "Put in its simplest form, the contrast between the hard and the soft refers to this distinction between the domain of nature, the object of attention of what we call the 'hard sciences', and the domain of culture." ${ }^{, 64}$ While reference to the hard and the soft can be found across the Serres's work, the concept finds a sustained treatment in the "Boxes" chapter of The Five Senses.

Breaking rocks, transporting them by the tonne, compacting their sharp edges into a solid mass, demands an energy output measurable in horsepower. On the other hand, drawing letters and crosses with a brush, red on white, recognizing their place within a code, makes energy demands that are not even comparable. The former is measured on the entropic scale, the latter on the informational scale. ${ }^{65}$

Writing is a particularly complicated site of convergence as the hard aspects of inscription meet the soft forms of encoding. When a proper name is engraved in stone, writing (a form of what Serres calls code) comes to rest in the entropic medium of stone. While the energy demands may not be comparable, by placing stone and inscription in a soft-hard continuum, Serres creates a communicative line between language and the lithic. "The difference between energy and information, physics and language" writes Steven Connor during a discussion of Serres, "is one of scale rather than kind" ${ }^{66}$ To inscribe a proper name in the hope of achieving an intimation of immortality is to fantasise about a form of technological singularity avant la lettre. As personhood is abstracted from the body to the linguistic sign, stone serves as a hard drive in which the software of subjectivity is inscribed. This is what Grossman means when he cryptically writes of an immortality predicated upon a delicate balance between stone and text. "When the message devours the stone, death ensues. When the stone usurps the message, death also". ${ }^{67}$ In Statues, Serres underscores the continuity between soft and hard forms by explicating the punning association in Matthew 16:18 between Peter [Pierre] and rock [pierre] in what becomes a foundational moment of slippage between the nominative and the lithic in early Christianity, what Joyce calls "thuartpeatrick" in an early version of Finnegans Wake. ${ }^{68}$

You are Peter [Pierre] and on this rock [pierre], I will build my Church. This founding sentence plays off a single word: the limestone thing, the corporeal 
flesh and the first name [...] from living or dead flesh to inert rock, thing or statue, from the body to its proper name [...] What, truly, remains stable across these change or substitutes if not the rock itself, always invariant and returning, in the word, the name, the body, the thing, the construction and the assembly. ${ }^{69}$

Proper names exist on a border between the linguistic and the material. The connection between rocks and names highlights the ambiguous material state of the nominal-as it serves as a base [pierre] upon which a superstructure of belief, subjectivity, and semiotics can be built [Pierre]. As the hard forms of stone flows into the soft forms of sign systems, proper names serve as a midpoint of convergence.

\section{Of Monads and Mud}

Serres is not the only thinker whose ears "still ring from stone-breaking" as a child. ${ }^{70}$ One of Beckett's enduring childhood memories features the sounds of stonecutters in the Dublin Mountains above Cooldrinagh. "The hammers of the stonecutters ring all day like bells.",71 When stone is paired with images of quarrying and extraction, lithic endurance gains an additional sense of differentiation and distinction. Conversely, softer forms begin to signify an undifferentiated state.

We see this in How It Is, the most mud-ridden of Beckett's writings. The text could be read as an imaginative tangent outward from a scene in Watt, where Mr. Spiro elaborates upon his nickname. "My friends call me Dum, said Mr. Spiro, I am so bright and cheerful. D-U-M. Anagram of mud". ${ }^{72}$ Another recombination of the terms in "First Love", proper names and their inversions comingle with mud, a particularly excremental material. The text makes this allotropic equation explicit through supposition: "if this so-called mud were nothing more than all our shit". ${ }^{73}$ By having his characters associate their names with mud and excrement instead of metal and stone, Beckett further inverts the tradition of preservation fantasy. Rather than remaining distinct through nominalization, the characters of How It Is undergo an immanent return to an undifferentiated state of being, embedding the human in the nonhuman.

As the narrator crawls through endless dirt, he writes the names of his two interlocutors ("Bom" and "Pim") in the mud. Discussing the appellation of Bom, the narrator describes him as "scored by finger-nail athwart the arse the vowel in the hole". ${ }^{74}$ Here the kinship between excrement and onomastics reaches a level unprecedented in Beckett, as the vowel "o" in "Bom" is compared through visual iconicity to a sphincter. Yet, the name is also "scored" by fingernail, echoing the tracing of "Lulu".

with the nail then of the right index in great capitals two full lines the shorter the communication the greater the capitals one has only to know a little beforehand what one wants to say he feels the great ornate letter [...] stab him 
simply in the arse that is to say speak and he will say anything what he can whereas proof I need proof so stab him in a certain way signifying answer. ${ }^{75}$

The fingernail that performs this scoring suggestively transforms into a crucifixion nail as it perforates Pim in order to "give him a name train him up bloody him all over with Roman capitals". ${ }^{76}$ The arse serves as both inkwell and stigmata-as the orifice becomes imaginatively equated with a puncture wound resulting from signification. To become Pim, he must first be perforated by a "good deep P", creating uncertainty as to whether it is mud or skin that is inscribed. The text continually plays with this ambiguity as mud becomes a messy extension of the body, through descriptions like "an arm colour of mud"77 and the "optical delusion" of excremental continuity: "when you shit it's the mud that wipes". ${ }^{78}$ Mud is even capable of becoming a dark mirror, echoing the almost biblical line in Play: "Mud thou art" ${ }^{79}$ After filling his mouth with mud, the narrator glimpses himself in the sludge, like a Narcissus of the mire: "another image the last there in the mud I say it as I hear it I see me". 80

One of the more cryptic sections of the text alludes to Ernest Haeckel, the German biologist and philosopher: "mad or worse transformed à la Haeckel". ${ }^{81}$ It is difficult to decipher what kind of transformation Beckett is implying until a few lines later, when the narrator speaks of "the different orders of the animal kingdom beginning with the sponges". 82 One of Haeckel's enduring pieces of research is a study of calcareous sponges, appearing in the second volume of Die Kalkschwaemme in 1872. The study led to his "Gastraea Theory", which proposed that "the ancestral mode of germ layer formation, or gastrulation, was by invagination to produce a functional gut". ${ }^{83}$ One of the sources for Haeckel's enduring, if now refuted, proposition that "ontogeny recapitulates phylogeny"-that the lifecycle of a single organism mirrors the evolution of that organism's phylum - is in the claim that "the gastrula stage can be found in the development of all animals, and represents the recapitulation of the ancestral metazoan, the Gastraea, a diploblastic animal with a ciliated gut". ${ }^{84}$ In this theory, all animals are descendants of the ancient Gastraea, as evidenced by the recapitulation of this form during gestational development.

Beckett clearly found inspiration for the almost ubiquitous "sack" of How It Is in the Gastraea. The narrator even uses Haeckel's word "recapitulate" when describing his relationship to sacks: "the mud the dark I recapitulate the sack" ${ }^{85}$ Beckett probably learned about Haeckel's philosophy via Wilhelm Windelband's A History of Philosophy from which he took extensive notes in the "Philosophy Notebooks". Windelband, however, mentions neither Gastraea nor the idea of ontogeny recapitulating phylogeny, choosing to focus instead on Haeckel's "so-called 'monism". ${ }^{86}$ In his essay "Monism as Connecting Religion and Science", Haeckel develops this line of thinking in a manifesto-like form.

By [monism] we unambiguously express our conviction that there lives "one spirit in all things," and that the whole cognisable world is constituted, and has been developed, in accordance with one common fundamental law. We emphasise by it, in particular, the essential unity of inorganic and organic nature, the latter having been evolved from the former only at a relatively late 
period. We cannot draw a sharp line of distinction between these two great divisions of nature, any more than we can recognise an absolute distinction between the animal and the vegetable kingdom, or between the lower animals and man. ${ }^{87}$

Later in the essay, Haeckel quotes Giordano Bruno. "There is one spirit in all things, and nobody is so small that it does not contain a part of the divine substance whereby it is animated. ${ }^{\prime 88}$ Even if Beckett never encountered Haeckel's monism directly, he found similar ideas in Bruno while researching "Dante ... Bruno . Vico .. Joyce", where he writes how "all things are ultimately identified with God, the universal monad, Monad of monads". 89

If monism describes an inherent unity that stretches across distinctions between animal, plant, and mineral, mud serves as a space of amalgam in which organic and inorganic material can recombine. One of Haeckel's most curious theories is that life arose from a kind of living "Urschleim" or primeval slime. He called the unicellular creatures that composed this primordial substance "Monera", writing that they are "not composed of any organs at all, but consist entirely of shapeless, simple homogeneous matter [...] nothing more than a shapeless, mobile, little lump of mucus or slime". ${ }^{90}$ After examining a mud-like substance dredged from the seafloor by a telegraph survey ship, biologist T.H. Huxley thought he had found Haeckel's Urschleim in the form of tiny calcareous plates, which he declared and named Bathybius haeckeli in $1868 .{ }^{91}$ While the discovery was soon debunked as nothing more than inorganic precipitate, and later labelled by Loren Eisely as "one of the most peculiar and fantastic errors ever committed in the name of science", the fantasy of Urschleim offers a materialist correlate to monist idealism. ${ }^{92}$ If life descended from primordial ooze, undistinguishable to the human eye from oceanic mud, then the distinction between the organic and inorganic begins to breakdown through association.

We find a similar kind of interconnection between inorganic and organic bodies that was intensely personal for Beckett. Beginning in his mid-twenties, the young writer was often plagued by cardiac arrhythmia — one of the conditions that led him to seek treatment with Wilfred Bion in London. In a letter to Mary Manning on 22 May, 1937, Beckett compared his troubled heart to Georges Pelorson's hardened chest. "Pelerson used to talk about the stone in his heart. I didn't know what he meant till I felt it myself. Cardiac calculus". ${ }^{93}$ His use of calculus ripples with polysemy, as both a medical term for mineral mass formed within the body and its better-known mathematical associations. Perhaps Beckett had something like Pelerson's heart in mind, when he wrote in Proust of the past being like a weighty stone carried inside of a person. "Yesterday is not a milestone that has passed, but a daystone on the beaten track of the years, and irremediably part of us, with us, heavy and dangerous".94 One has to also wonder if the sucking stone scene in Molloy is not a play upon this double meaning of calculus: as pebbles move in and out of the body, forming a complex system of calculation.

\section{Conclusion: A Return to the Mineral State}


In a rare autobiographical gloss upon his childhood interest in the mineral world, Beckett associates geophilia with a desire to return to an undifferentiated state. As James Knowlson records:

He recounted how he used to take stones of which he was particularly fond home with him from the beach in order to protect them from the wearing away of the waves or the vagaries of the weather. [...] Later in life, he came to rationalize this concern as the manifestation of an early fascination with the mineral, with things dying and decaying, with petrification. He linked this interest with Sigmund Freud's view that human beings have a prebirth nostalgia to return to the mineral state. ${ }^{95}$

Beckett is referring to what Freud, at certain points in his career, characterized as either death drives or death instincts. Since animate subjects arise from an inanimate state and return to a similar condition, Freud hypothesized a sedimentary drive or desire urging distinct subjects back toward indistinction. In Beyond the Pleasure Principle, Freud writes of "an urge inherent in organic life to restore an earlier state of things which the living entity has been obliged to abandon under the pressure of external disturbing forces; that is, it is a kind of organic elasticity, or, to put it another way, the expression of an inertia inherent in organic life" ${ }^{96}$ While Freud does not speak explicitly of a "mineral state" when talking about the death drive, he uses the metaphor for different purposes in his Introductory Lectures on Psychoanalysis. "Consider the difference between the study of minerals and of rocks in mineralogy. The minerals are described as individuals, no doubt on the basis of the fact that they often occur as crystals, sharply separated from their environment." 97 Here we find the metaphor of separating the part from the whole, which Beckett recombines with a deathbound instinct.

By returning the part to the whole, showing how proper names interact with mud and excrement to evoke an undifferentiated state, Beckett inverts the traditional preservation fantasy inherited from the lyric tradition. In doing so, he recasts inscription as a tool for bridging worlds human and nonhuman. Just as Arsene longs to be transformed into a cromlech - and the bodies in How It Is merge with mud-Beckett uses inscription to think through the allotropic continuity between hard and soft forms. The return to a "mineral" or nonhuman state is perhaps most palpable in "The End" (1949), when the narrator describes becoming particulate after death. "Just under the surface I shall be, all together at first, then separate and drift, through all the earth and perhaps in the end through a cliff into the sea, something of me." 98 This material dispersal of self finds an antecedent in Murphy (1938), where the titular character is cremated and scattered across the floor of a pub. "By closing time the body, mind and soul of Murphy were freely distributed over the floor of the saloon; and before another dayspring greyened the earth had been swept away with the sand, the beer, the butts, the glass, the matches, the spits, the vomit". ${ }^{99}$ It is not surprising ${ }^{100}$ that Murphy - "who was not tied by interest to a corpse-obedient matter and whose best friends had always been among things" 101 —would find himself irreversibly comingled with 
nonhuman detritus, finding material afterlife in waste matter, itself a form of excremental inscription.

\section{Notes:}

${ }^{1}$ Ibsen, When We Dead Awaken, 28; translation modified.

${ }^{2}$ DeLillo, Point Omega, 53.

${ }^{3}$ Beckett, Short Prose, 26.

${ }^{4}$ Beckett, Short Prose, 26; for a comparative reading of the English and French versions of this epitaph, see Ricks, Beckett's Dying Words, 164.

${ }^{5}$ Dickens, Great Expectations, 43.

${ }^{6}$ Mark Nixon and Dirk Van Hulle summarise this position, writing that "Beckett's attention in these years [was focussed] on writers as diverse as Proust, Joyce, Schopenhauer or St. Augustine, even if Shakespeare, Dickens, and Chaucer, to name just these, make fleeting appearances" (Samuel Beckett's Library, 21). And yet, the many allusions to Dickens in Beckett's corpus imply that the influence is more than fleeting. "Despite such allusions as this", writes Paul Stewart, "the role of Dickens in the works of Beckett has been all but ignored" ("But Why Shakespeare", 207).

${ }^{7}$ Beckett, Disjecta, 49-50.

${ }^{8}$ Beckett, Disjecta, 49-50.

${ }^{9}$ Abram, Spell of the Sensuous, 100.

${ }^{10}$ Dickens, Great Expectations, 3; original emphasis.

${ }^{11}$ Knowlson, Damned to Fame, 46.

12 Keatinge, "Stone-cutters", 322.

${ }^{13}$ See, for example: O’Nan 2014; Hramova 2010; Kawashima 2008; Feshbach 1993; Levitt 1977.

${ }^{14}$ See, for example: Stillman 2014; Barry 2007.

${ }^{15}$ See, for example: Nixon 2009; Begam 1996.

${ }^{16}$ Feldman, Beckett/Philosophy, 37.

${ }^{17}$ I am thinking especially of a vital-materialist strain developed by Jane Bennett $(2010 ; 2001)$ and Jerome Jeffrey Cohen (2015).

${ }^{18}$ Kunin, "Shakespeare's Preservation Fantasy", 92.

${ }^{19}$ Grossman, The Sighted Singer, 210-212.

${ }^{20}$ Kunin, "Shakespeare's Preservation Fantasy", 94.

${ }^{21}$ Grossman, The Sighted Singer, 290.

${ }^{22}$ Like the speaker of Edmund Spenser's "Amoretti LXXV", who tells his addressee that his verse "your virtues rare shall eternize / And in the heavens write your glorious name", this kind of poetics is built upon an imaginative association between names, an enduring medium like stone, and inscription (Spenser's Shorter Poetry, 75). Take, for example, Shakespeare's LV sonnet, in which poetry long outlasts even the strongest marble: "Not marble, nor the gilded monuments / Of princes shall outlive this powerful rhyme; / But you shall shine more bright in these contents / Than unswept stone besmeared with sluttish time" (Sonnets, 4). Here verse is set against stone, as language becomes a new and improved medium of preservation. Contrast this to Wordsworth's "To Joanna", a poem about a literal act of lithic inscription. "I chiseled out in those rude characters / Joanna's name deep in the living stone:-- / And I, and all who dwell by my fireside, / Have called the lovely rock, Joanna's rock" (Lyrical Ballads, 186). By writing a poem about engraving, Wordsworth permanently entwines his poem with its object. It is difficult to read "To Joanna" as anything else but the poetic elaboration of Joanna's rock - a field of inscription facilitating Grossman's conservation of names. Taking an article by Anne Stillman on Beckett, Wordsworth, and lyric slightly out of context, we find that '“rock' and 'voice' co-exist 'together' in a live and life-long dance that sets in motion all that has already been in time before" (Beckett's Lyrical Ballads, 137). Closer to Beckett's time and reading, there are poems like Yeats's "Sailing to Byzantium", where the speaker dreams of being gathered "[i]nto the artifice of eternity" by substituting his body for "hammered gold and gold enameling" (Poems, 73). Metal stands in for stone, but the preservation fantasy remains intact, as the corporal signature replaces the written name. In "Easter, 1916", Yeats attempts to immortalize political figures rather than erotic objects by naming the Irish republican leaders who 
staged the Easter Rising. "I write it out in a verse - / MacDonagh and Macbride / And Connolly and Pearse" (Poems, 118). Yeats achieves a memorial tone of enduring permanence by making frequent allusions to the lithic, writing that "Too long a sacrifice / Can make a stone of the heart" and reminding his reader that " $[\mathrm{t}] \mathrm{he}$ stone's in the midst of all" (118). Samuel Johnson offers an early theoretical treatment of this tradition, showing how names moves from lithic to cultural memory in his "Essay upon Epitaphs". "To expose the absurdity of this omission [of the proper name], it is only necessary to ask how the Epitaphs, which have outlived the stones on which they were inscribed, would have contributed to the information of posterity, had they wanted the name of those whom they celebrated" ("Essay on Epitaphs", xii). Beckett would have been closely familiar with the "Essay upon Epitaphs" from the research that went into drafting Human Wishes, his abandoned play about Johnson's life. It would be naïve, however, to associate this tradition solely with Anglophone literature. John MacKay (2006) has shown how the questions of inscription, materiality, and preservation were taken up in the modern period across European literature (English, Russian, German, and French), while Geoffrey Hartman (1970) and Joshua Scodel (1991) have drawn lines of inheritance between the modern epitaph and similar Greek and Latin forms. If my focus is solely on Anglophone texts here, it is because I am more interested in showing how Beckett reconfigures certain multilingual associations between proper names, inscription, and stone, less in drawing direct lines of influence between his texts and a particular literature.

${ }^{23}$ Beckett, Short Prose, 29-30.

${ }^{24}$ Beckett, Short Prose, 34.

${ }^{25}$ Beckett, Short Prose, 34-5.

${ }^{26}$ Beckett, Short Prose, 33-34.

${ }^{27}$ Joyce, Finnegans Wake, 185.27-186.10.

${ }^{28}$ Kristeva, Desire in Language, 149.

${ }^{29}$ Ackerley in Barfield et al., Beckett and Death, 216.

${ }^{30}$ Acheson in Ben-Avi, Women in Beckett, 225.n2.

${ }^{31}$ Wedekind, The Lulu Plays, 33.

${ }^{32}$ Wedekind, The Lulu Plays, 29.

${ }^{33}$ Hulle and Nixon, Samuel Beckett's Library, 83.

${ }^{34}$ Robertson, History, 519. It needs mentioning that "Lulu" would have been a well-known character for someone with knowledge of Weimar cinema. G.W. Pabst's adaptation of Wedekind's Lulu plays, Die Büchse der Pandora, features Louise Brooks as Lulu, who would eventually become "a Paris cult figure in 1930" (Elsaesser, Weimar Cinema, 259). It is difficult to know if Beckett would have seen the film. While widely known and discussed in Germany at the time of its release, after 1945 the film became unavailable for several decades, except for the occasional screening in Henri Langlois's Cinematheque in Paris - a cinema Beckett supported, at least in signature, when Cahiers du Cinéma petitioned Langlois's dismissal in 1968. And yet, the renaming of "Lulu" is not recorded in the Heinemann or Robertson, nor was it written into Pabst's film script, seeming to suggest that Beckett also engaged with Wedekind's primary source material sometime in the late 1930s.

${ }^{35}$ Jacobs, Naming-Day in Eden, 43.

${ }^{36}$ Joyce, Ulysses, 7.690-1

37 Ackerley, Demented Particulars, 28.1.

${ }^{38}$ Beckett, Collected Poems, 20.

${ }^{39}$ Wheatley in Bryden, Beckett and Animals, 216. In a letter to Eva Hesse on 14 Feburary 1957, Beckett offers a different gloss of 'strippin', writing that it means 'taken: surprised, caught' (Collected Letters III, 23).

${ }^{40}$ John 8:7, King James Version.

${ }^{41}$ Beckett, Watt, 43.

${ }^{42}$ Beckett, Watt, 61, emphasis mine.

${ }^{43}$ Beckett, Watt, 45.

${ }^{44}$ Quoted in Knowlson, Damned to Fame, 160.

${ }^{45}$ Bonwick, Irish Druids, 212.

${ }^{46}$ Bonwick, Irish Druids, 61.

${ }^{47}$ Toland, History, 130-1. 
${ }^{48}$ Jennings, Rosicrucians, 107

${ }^{49}$ Spence, The Magic Arts, 162.

${ }^{50}$ Myles na gCopaleen, The Irish Times, July 30, 1947, 4.

${ }^{51}$ Quoted in Russell, Songs by the Way, ii.

${ }^{52}$ Morin, “Odds, Ends, Beginnings", 211-212.

${ }^{53}$ Beckett, Watt, 58.

${ }^{54}$ Beckett, Watt, 167.

${ }^{55}$ Proust, Swann's Way, 45.

${ }^{56}$ Joyce, Ulysses, 4.333.

${ }^{57}$ Beckett, Letters II, 208.

${ }^{58}$ Beckett, Disjecta, 70.

${ }^{59}$ Beckett, Molloy, 107-8.

60 “Oy”, Oxford English Dictionary.

${ }^{61}$ Beckett, Molloy, 42.

${ }^{62}$ Beckett, Malone Dies, 216; in French, Beckett uses "tendre" for soft: "Entre une mine dure [...] et une mine tendre" (Malone Meurt, 97).

${ }^{63}$ Beckett, Molloy, 9; in French, Beckett uses "le mou" for "soft": "le dur, le liquide et le mou" (Molloy, 35).

${ }^{64}$ Connor, "The Hard and the Soft", 3.

${ }^{65}$ Serres, The Five Senses, 112.

${ }^{66}$ Connor, "The Hard and the Soft", 6.

${ }^{67}$ Grossman, The Sighted Singer, 297.

${ }^{68}$ Joyce, Selected Letters, 316; Ellmann, James Joyce, 583.

${ }^{69}$ Serres, Statues, 174-5.

${ }^{70}$ Serres, The Five Senses, 112.

${ }^{71}$ Beckett, Malone Dies, 286.

${ }^{72}$ Beckett, Watt, 12.

${ }^{73}$ Beckett, How It Is, 58

${ }^{74}$ Beckett, How It Is, 67.

${ }^{75}$ Beckett, How It Is, 78-9.

${ }^{76}$ Beckett, How It Is, 69.

${ }^{77}$ Beckett, How It Is, 114.

${ }^{78}$ Beckett, How It Is, 41.

${ }^{79}$ Beckett, Complete Dramatic Works, 205.

${ }^{80}$ Beckett, How It Is, 31.

${ }^{81}$ Beckett, How It Is, 42. For a different take on Haeckel's influence on Beckett, see Wimbush, "Biology, the Buddha and the Beasts".

${ }^{82}$ Beckett, How It Is, 43.

${ }^{83}$ Leys and Eerkes Medrano, "Sponges", 342.

${ }^{84}$ Haeckel in Leys and Eerkes Medrano, "Sponges", 344.

${ }^{85}$ Beckett, How It Is, 8. This works in the original French as well: "le noir récapitulons le sac" (Comment C'est, $11)$.

${ }^{86}$ Windelband, History, 643.

${ }^{87}$ Haeckel, Monism, 13.

${ }^{88}$ Haeckel, Monism, 17.

${ }^{89}$ Beckett, Disjecta, 34.

${ }^{90}$ Haeckel, History of Creation, 189.

${ }^{91}$ Rehbock, "Huxley, Haeckel”, 504.

${ }^{92}$ Eiseley, The Immense Journey, 34-5.

${ }^{93}$ Quoted in Knowlson, Damned to Fame, 136.

${ }^{94}$ Beckett, Proust, 13.

${ }^{95}$ Knowlson, Damned to Fame, 46. 
${ }^{96}$ Freud, Beyond the Pleasure Principle, 36.

${ }^{97}$ Freud, Introductory Lectures on Psychoanalysis, 484.

${ }^{98}$ Beckett, Short Prose, 160.

${ }^{99}$ Beckett, Murphy, 101.

${ }^{100}$ Murphy is a text rich in allotropic reconfigurations. An extended version of this article would account for disintegration, sublimation, and Beckett's gaseous imagination. For a reading of the interrelation of gas and chaos in Murphy, see Ebury, Modernism and Cosmology, 149-53.

${ }^{101}$ Beckett, Murphy, 114.

\section{Works Cited:}

Abram, David. The Spell of the Sensuous: Perception and Language in a More-than-human World. New York: Pantheon, 1996. Print.

Ackerley, Chris, and Samuel Beckett. Demented Particulars: The Annotated Murphy. Edinburgh: Edinburgh UP, 2010. Kindle Book.

Barfield, Steven, Philip Tew, and Matthew Feldman. Beckett and Death. London: Continuum, 2009. Print.

Barry, Elizabeth. "THE LONG VIEW: Beckett, Johnson, Wordsworth and the Language of Epitaphs." Samuel Beckett Today / Aujourd'hui 18."All Sturm and No Drang": Beckett and Romanticism, Beckett at Reading 2006 (2007): 47-60. JSTOR. Web. 16 Mar. 2016.

Beckett, Samuel. The Complete Dramatic Works of Samuel Beckett. London: Faber and Faber, 2006. Print.

---. Collected Poems of Samuel Beckett. London: Faber and Faber, 2012. Print.

---. Comment C'est; Roman. Paris: Éditions De Minuit, 1961. Print.

---. The Complete Short Prose, 1929-1989. Ed. S. E. Gontarski. New York: Grove, 2002. Print.

---. Disjecta: Miscellaneous Writings and a Dramatic Fragment. Ed. Ruby Cohn. New York: Grove Press, 1983. Print.

---. The Letters of Samuel Beckett. Vol. 2, 1941-1956, Cambridge: Cambridge UP, 2011. Print.

---. The Letters of Samuel Beckett. Vol. 3, 1956-1963, Cambridge: Cambridge UP, 2014. Print.

---. Malone Dies. London: Faber \& Faber, 2010. Print.

---. Malone Meurt. Paris: Éditions De Minuit, 2004. Print.

---. Molloy. London: Faber \& Faber, 2009. Print.

---. Molloy. Paris: Éditions De Minuit, 1982. Print.

---. Murphy. London: Faber \& Faber, 2009. Print.

---. Proust and Three Dialogues with Georges Duthuit. London: John Calder, 1999. Print.

---. The Unnamable. London: Faber \& Faber, 2010. Print. 
---. Watt. London: Faber \& Faber, 2009. Print.

Begam, Richard. Samuel Beckett and The End of Modernity. Stanford: Stanford University Press, 1996. Print.

Bennett, Jane. The Enchantment of Modern Life: Attachments, Crossings, and Ethics. Princeton, NJ: Princeton UP, 2001. Print.

---. Vibrant Matter: A Political Ecology of Things. Durham: Duke UP, 2010. Print.

Ben-Zvi, Linda. Women in Beckett: Performance and Critical Perspectives. Urbana: U of Illinois, 1990. Print.

Bonwick, James. Irish Druids and Old Irish Religions. New York: Dorset, 1986. Print.

Bryden, Mary, ed. Beckett and Animals. Cambridge: Cambridge UP, 2013. Print.

Cohen, Jeffrey Jerome. Stone: An Ecology of the Inhuman. Minneapolis: U of Minnesota P, 2015. Print.

Connor, Steven. "Michel Serres: The Hard and the Soft.” 2009. http://stevenconnor.com/hardsoft/hardsoft.pdf. Web.

DeLillo, Don. Point Omega. London: Picador, 2011. Print.

Dickens, Charles, and Charlotte Mitchell. Great Expectations. London: Penguin, 2003. Print.

Ebury, Katherine. Modernism and Cosmology: Absurd Lights. London: Palgrave, 2014. Print.

Eiseley, Loren C. The Immense Journey. New York: Random House, 1957. Print.

Ellmann, Richard. James Joyce. Oxford: Oxford UP, 1982. Print.

Elsaesser, Thomas. Weimar Cinema and After: Germany's Historical Imaginary. London: Routledge, 2000. Print.

Feldman, Mathew. “'I am not a philosopher.' Beckett and Philosophy: A Methodological and Thematic Overview”, in Feldman, M., and Mamdani, K., (eds.) Beckett / Philosophy. Stuttgart: ibidem, 2015,

Feshbach, Sidney. "On Names in James Aloysius Augustine Joyce and Samuel Barclay Beckett." The Massachusetts Review 34.4 (1993): 593-615.

Freud, Sigmund, James Strachey, and Gregory Zilboorg. Beyond the Pleasure Principle. New York: Norton, 1975. Print.

---. and James Strachey. Civilization and Its Discontents. New York: Norton, 2005. Print.

---. Sigmund, and James Strachey. Introductory Lectures on Psychoanalysis. New York: Norton, 1977. Print.

Grossman, Allen R., Mark Halliday, The Sighted Singer: Two Works on Poetry for Readers and Writers. Baltimore: Johns Hopkins UP, 1992. Print.

Haeckel, Ernst. The History of Creation. Ed. Sir Edwin Ray Lankester. London: Kegan Paul, 1883. Print. 
---. Monism as Connecting Religion and Science: The Confession of Faith of a Man of Science. A. and C. Black, 1895. Print.

Hartman, Geoffrey H. Beyond Formalism; Literary Essays, 1958-1970. New Haven: Yale UP, 1970. Print.

Hramova, Tatyana. "The Study of Names in Samuel Beckett's Texts: Problems and Prospects." Names 58.1 (2010): 5-12.

Hulle, Dirk Van, and Mark Nixon. Samuel Beckett's Library. New York: Cambridge UP, 2013. Print.

Ibsen, Henrik. When We Dead Awaken. Michael Meyer (trans). London: Rubert Hart-Davis, 1960. Print.

Jacobs, Noah J. Naming-day in Eden; the Creation and Recreation of Language. New York: Macmillan, 1958. Print.

Jennings, Hargrave. The Rosicrucians, Their Rites and Mysteries: With Chapters on the Ancient Fire and Serpent-worshippers, and Explanations of the Mystic Symbols Represented in the Monuments and Talismans of the Primeval Philosophers. New York: J.W. Bouton, 1879. Print.

Johnson, Samuel. A Collection of Epitaphs and Monumental Inscriptions, Historical, Biographical, Literary, and Miscellaneous. To Which Is Prefixed, An Essay on Epitaphs. London: Lackington, Allen, 1806. Print

Joyce, James. Finnegans Wake. New York: Viking, 1969. Print.

---. Hans Walter Gabler, Wolfhard Steppe, and Claus Melchior. Ulysses: The Corrected Text. New York: Random House, 1986. Print.

---. Selected Joyce Letters. Ed. Richard Ellmann. New York: Viking, 1966. Print.

Kawashima, Takeshi. "WHAT KIND OF NAME IS THAT?: Samuel Beckett's Strategy of Naming." Samuel Beckett Today/Aujourd'hui (2008): 327-337.

Keatinge, Benjamin. "'The Hammers of the Stone-Cutters': Samuel Beckett's Stone Imagery." Irish University Review 37.2 (2007): 322-39. JSTOR. Web. 16 Mar. 2016.

Knowlson, James. Damned to Fame: The Life of Samuel Beckett. New York: Grove Press, 1996. Print.

Kristeva, Julia. Desire in Language: A Semiotic Approach to Literature and Art. New York: Columbia UP, 1980. Print.

Kunin, Aaron. "Shakespeare's Preservation Fantasy." PMLA 124.1 (2009): 92-106. JSTOR. Web. 16 Mar. 2016.

Levitt, Jesse. "Names in Beckett's Theater: Irony and Mystification." Literary Onomastics Studies 4.1 (2014).

Leys, Sally P., and Dafne Eerkes-Medrano. "Gastrulation in calcareous sponges: in search of Haeckel's gastraea." Integrative and comparative biology 45.2 (2005): 342-351.

MacKay, John. Inscription and Modernity: From Wordsworth to Mandelstam. Bloomington: Indiana UP, 2006. Print. 
Morin, Emilie. "Odds, Ends, Beginnings: Samuel Beckett and Theatre Cultures in 1930s Dublin”, in S.E. Gontarski (ed.) The Companion to Samuel Beckett and the Arts, Edinburgh: Edinburgh University Press, 2014, 209-21.

Nixon, Mark. "Writing myself into the ground", in Barfield, S., Feldman, M. and Tew, P. (eds.) Beckett and Death. London: Continuum, 2009.

O'Nan, Martha. "Names In Samuel Beckett's Waiting For Godot." Literary Onomastics Studies 6.1 (2014): 17.

Proust, Marcel, C. K. Scott-Moncrieff, Joseph Wood Krutch, and F. A. Blossom. Remembrance of Things past. New York: Random House, 1934. Print.

Rehbock, Philip F. "Huxley, Haeckel, and the Oceanographers: The Case of Bathybius Haeckelii." Isis 66.4 (1975): 504-33. Web.

Ricks, Christopher. Beckett's Dying Words: The Clarendon Lectures, 1990. Oxford: Oxford UP, 1993. Print.

Robertson, John George. A History of German Literature. New York: Putnam, 1902. Print.

Russell, George William. Homeward: Songs by the Way. Dublin: Whaley, 1894. Print.

Scodel, Joshua. The English Poetic Epitaph: Commemoration and Conflict from Jonson to Wordsworth. Ithaca, NY: Cornell UP, 1991. Print.

Serres, Michel. Statues: The Second Book of Foundations. London: Bloomsbury, 2015. Print.

---. The Five Senses: A Philosophy of Mingled Bodies (I). London: Continuum, 2009. Print.

Shakespeare, William. Shakespeare's Sonnets. Ed. Stephen Booth. New Haven: Yale UP, 1997. Print

Spence, Lewis. The Magic Arts in Celtic Britain. London, NY: Rider, 1945. Print.

Spenser, Edmund. Spenser's Shorter Poetry. Ed. William Oram, Einar Bjorvind, and Ronald Bond. New Haven: Yale UP, 1989. Print.

Stewart, Paul. "But Why Shakespeare? The Muted Role of Dickens in Endgame." Samuel Beckett's Endgame. Ed. Mark Byron. Amsterdam: Rodopi, 2007. 207-26. Print.

Stillman, Anne. “Samuel Beckett’s Lyrical Ballads.” Thinking Verse IV.i (2014): 110-139. Web. 26 Sep. 2016.

Toland, John. The History of the Celtic Religion and Learning: Containing an Account of the Druids, or the Priests and Judges, of the Vaids, or the Diviners and Physicians, and of the Bards, or the Poets and Heralds, of the Ancient Gauls, Britons, Irish, and Scots: With the History of Abaris, the Hyperborian, Priest of the Sun. Norwood, PA: Norwood Editions, 1976. Print.

Wedekind, Frank, and Stephen Spender. The Lulu Plays \& Other Sex Tragedies. London: Calder, 2000. Print.

Wimbush, Andy. "Biology, the Buddha and the Beasts: The Influence of Ernst Haeckel and Arthur Schopenhauer on Samuel Beckett's How It Is." Encountering Buddhism in Twentieth-century British and American Literature. Ed. Lawrence Normand and Alison Winch. London: Bloomsbury, 2013. N. pag. Print.

Windelband, W. A History of Philosophy. Volume II: Renaissance, Enlightenment and Modern. New York: 
Harper, 1958. Print.

Wordsworth, William. Lyrical Ballads with Other Poems. London, 1800. Print.

Yeats, W. B., and Richard J. Finneran. The Poems. New York: Macmillan, 1989. Print. 